\title{
Learning Slope
}

National Cancer Institute

\section{Source}

National Cancer Institute. Learning Slope. NCI Thesaurus. Code C162252.

A measure of an individual's learning rate. 